\title{
TTR
}

Traduction, terminologie, re?daction

\section{The Three Companions}

\section{W. H. Auden}

Volume 12, numéro 2, 2e semestre 1999

Poésie, cognition, traduction II - Autour d'un poème de W. H. Auden

Poetry, Cognition, Translation II — On a Poem by W. H. Auden

URI : https://id.erudit.org/iderudit/037366ar

DOI : https://doi.org/10.7202/037366ar

Aller au sommaire du numéro

\section{Éditeur(s)}

Association canadienne de traductologie

ISSN

0835-8443 (imprimé)

1708-2188 (numérique)

Découvrir la revue

Citer ce document

Auden, W. H. (1999). The Three Companions. TTR, 12(2), 9-9.

https://doi.org/10.7202/037366ar d'utilisation que vous pouvez consulter en ligne.

https://apropos.erudit.org/fr/usagers/politique-dutilisation/ 


\section{AUTOUR D'UN POÈME DE W. H. AUDEN}

\section{The Three Companions}

«O where are you going? » said reader to rider, "That valley is fatal when furnaces burn, Yonder's the midden whose odours will madden, That gap is the grave where the tall return. "

«O do you imagine, » said fearer to farer, " That dusk will delay on your path to the pass, Your diligent looking discover the lacking Your footsteps feel from granite to grass? ')

«O what was that bird, » said horror to hearer, «Did you see that shape in the twisted trees? Behind you swiftly the figure comes softly, The spot on your skin is a shocking disease. "

" Out of this house » - said rider to reader, " Yours never will » - said farer to fearer, " They're looking for you " - said hearer to horror As he left them there, as he left them there.

W. H. Auden. A Selection by the Author (1950 [1932]) 